\title{
Smart training technology in the teaching of history at Kazan State University of Architecture and Engineering
}

\author{
Elena Bureeva $^{1 *[0000-0002-2274-9931]}$, and Natalya Mukhinova ${ }^{1 \text { [0000-0003-3453-6332] }}$ \\ ${ }^{1}$ Kazan State University of Architecture and Engineering, 420043 Kazan, Russia
}

\begin{abstract}
The smart training technologies include several parts. Their joint use allows making students of technical higher educational institutions interested in studying history. This article describes the experience of involving students of a construction university in research activities in history classes, when studying the topic of the Great Patriotic War. The first stage of the work involves the study of the student's historical memory, the students' perceptions of this war through direct communication of the professor with students, the integrated use of sociological, linguistic, pedagogical, psychological methods. In the framework of a continuous survey of 346 students, an expressed emotional coloring of the image of war in the student consciousness and solidarity of students in the need to preserve the memory of the war were revealed. Students classified the written and oral stories of the contemporaries, primarily their relatives, as the most reliable sources on the history of the war. Given the influence of the family war memory, professors form students' interest in research activities. At the next stage, an individual strategy for writing a family history of wartime is developed for each student; recommendations are given on working with databases, information available on the Internet, family and state archives, libraries.
\end{abstract}

Keywords. Smart technologies, value orientation, student youth, pedagogical technologies, historical memory.

\section{Introduction}

Recently, many researchers have noted the need to use smart training technologies at the universities [1]. The smart training technology can be used for students of a building university to teach humanities, such as history. The concept of «smart training» is quite broad and may include several methods and technologies. Firstly, it is the establishment of a connection between the students' everyday experience and the scientific study of history as a science, which is based on a training approach that allows them to connect their daily lives and the world of science. The main problem for science education today is the gap between the everyday and the scientific knowledge of students; this gap often causes alienation among students and is one of the reasons for the decline in interest in science. This is reflected in the studies [2-6]. Secondly, this is the ability to work with information that comes through

*Corresponding author: bureeva27@yandex.ru 
Internet resources. In modern society, young people are the most receptive social audience to the values, opinions, views expressed by the Internet space [7-11]. Even viewing of publications, blogs of science-dubious content is fraught with the danger of accepting these values, breaking the social and cultural identity, and the birth of extremist sentiments. Thirdly, this is the construction of a system for mastering knowledge in the process of formal and non-formal training. Higher educational institutions possess great potential in the formation of a competent, educated, harmonious personality, especially in the study of humanitarian disciplines. The professor's ability to engage the student in the cognitive process and the student's personal interest in the study of science, which is formed when it comes into contact with his life experience and everyday life, plays a large role. This is noted in the works [12-15]. Classroom lectures on history make it possible to track students' mood, their assessments and interpretations of the past and present, personal and collective attitude to events, processes, and personalities, contribute to the formation of historical literacy, socio-cultural identification. Researchers note the great importance of the survey and questionnaire among students as a method to determine the attitude of students to the historical past of the country $[16,17]$. In the fourth place is the ability to use electronic databases on the Internet to search and process scientific information.

The smart training technologies can be applied in the study of the history of the Second World War of 1939-1945. The theme of the war is relevant and valuable for Russian society. Russian and foreign politicians with loud statements fuel public interest in the Second World War, scientists are trying to write an objective history of the war, directors of feature films give a modern sound to the events of 1941-1945. All this affects the formation, maintenance, transformation of the image of war in the collective memory of Russian society. The problem of patriotic education in the process of formation of historical collective students' memory is considered in the works [18-20]. Students are also subject to these influences. Russian events, such as the «St. George Ribbon» and the «Immortal Regiment», help raise questions: «What does the war have to do with me and my family?» The search for answers to questions gives rise to a certain attitude to the events of 1941-1945, forms a generalized image of war. The theme of war makes it possible to attract a student through personal interest to historical research activities.

Using the methodology of interviewing students in the process of smart training makes it possible not only to identify the value orientations of students, but also to influence their formation.

\section{Materials and methods}

In this article, we explore several aspects of smart training, through which students, communicating with professors, parents, and participants in the war, connect their everyday experience with the process of teaching history. In order to interest students of a technical university in historical science, it is necessary to study their value orientations, teach them how to work with electronic resources, and teach them how to work in a group. A survey of students was conducted that revealed their attitude to the events of wartime, trust in historical sources, which made it possible to determine the personal and social orientations of students, their attitude to the events of the war. The volume of the sample, compiled through a continuous study, amounted to 346 first-year students of Kazan State University of Architecture and Engineering (KSUAE).

\section{Results}

The meeting of the history professor with university students takes place in the first year of bachelors and specialists in lectures and practical classes on history. The student community of KSUAE includes representatives from various regions of the Russian Federation and foreign countries. As a result of this, the university's student audience is multiethnic, multiconfessional, 
multicultural. The collective place of memory, consolidating the student community, is the memory of the Great Patriotic War. Preservation of historical memory is possible through communication with people who survived these events [2]. Over time, historical memory is transformed, filled with new images and approaches. This leads to the fact that in working with student youth it is necessary to use new teaching technologies that contribute to the involvement of the student in science through emotional influence, involvement in the process of cognition, the development of imagination, student communication, and interest in historical science increases [4].

Kazan State University of Architecture and Engineering has developed and tested a system for involving students in research activities, based on the integrated use of pedagogical, linguistic, psychological, sociological techniques, methods and technologies.

Communication with students at the first stage of work is based on a soft, unobtrusive approach. Introductory interviews, anonymous polls. As a result of the preliminary interview, the professor asks students to give answers that reflect their own opinions. An anonymous nature allows young people to give truthful answers without fear of the professor's reaction. Respondents indicate in the questionnaires only age and gender. The survey makes it possible to find out the attitude of students and the degree of their trust in historical sources and sources from family archives.

At our disposal there is a complex of similar profiles. In this paper, we present one of the options.

Questionnaire 1 a.

«Memory of the Great Patriotic War».

Dear friends!

We ask you to answer the proposed questions.

1. What are the 5 words, phrases that you associate with the concept of «Great Patriotic War»? (Answers should be given quickly, without hesitation, writing down the first options that came to mind. If you can't remember 5 words, phrases, you can specify a smaller number of options).

2. In your opinion, is it necessary to preserve the memory of the Great Patriotic War? (Answer «yes» or «no», if possible, justify your answer).

3. How to keep the memory of the war?

(Think about what efforts the state, society, individuals, institutions, personally you do in this direction. What events, promotions and other events do you consider excessive, untimely, unnecessary, and which, on the contrary, are important and necessary? What else needs to be done in this direction?

4. What are the most reliable sources about the Great Patriotic War?

(Think about the sources you know about the war, which one you trust the most. If there are several, rank them according to the degree of certainty from the highest to the lowest. You can name those sources that you should not trust in any case).

5. Is the story of the Great Patriotic War preserved in your family?

(Answer «yes» or «no». If «yes», then how. Who of your relatives (without names and surnames), lived during the Second World War, you can talk about?).

During the period of 2019-2020 academic year 346 first-year students of KSUAE answered the questions of this questionnaire, including 193 males and 153 females. An analysis of the responses showed the following results.

In the first question of the questionnaire, the method of associative experiment was used, which is now popular with linguists, psychologists, sociologists, political scientists. In our case, this method makes it possible to construct a generalized image of the Great Patriotic War, available in the minds of students, and therefore to evaluate the content of the student's historical memory of this military conflict.

Among the total number of 1505 associations cited, the negative ones are $52 \%$, the positive ones are $15 \%$, and the neutral ones are $33 \%$.

The most common associations are presented in Table 1. 
Table 1. Associations given to the concept of the «Great Patriotic War».

\begin{tabular}{|c|l|c|c|c|}
\hline № & \multicolumn{1}{|c|}{ Associations } & Men & Women & Total \\
\hline 1 & Losses & 47 & 43 & 90 \\
\hline 2 & Tears of happiness & 29 & 52 & 81 \\
\hline 3 & People & 38 & 41 & 79 \\
\hline 4 & Joy & 30 & 35 & 65 \\
\hline 5 & Fear & 28 & 31 & 59 \\
\hline 6 & Pain & 26 & 30 & 56 \\
\hline 7 & Holiday & 19 & 21 & 40 \\
\hline 8 & Liberty & 20 & 11 & 31 \\
\hline 9 & Feat & 17 & 9 & 26 \\
\hline 10 & Pride & 12 & 9 & 21 \\
\hline
\end{tabular}

The data in the table indicate that the image of war among young people has an expressed emotional coloring; in the description such emotions as joy, fear, and pain prevail. The war for respondents is primarily associated with heavy losses, and not with specific historical figures, military operations, and accomplished feats. The student audience presents the Second World War as a difficult test. The victory was won by the incredible efforts of the whole people, which cause a feeling of pride.

There are also such associations (up to 20 references) such as cruelty, death, war, blood, grief, hunger, crying, cold. Such associations are single - what for was it all?, alcoholism of the grandfather, single mothers, the main brace of the country, war films, deep breaths, tinnitus, dawn, historical event, Nuremberg trials, monument. One of the respondents replied: «The landscape is foggy, gloomy, soldiers, battle (like a frame from a film)». Most likely, it was in the form of a frame from the film that the image of war was embodied in the students' consciousness in the form of a tragic historical event that brought the population many deaths, grief, pain, fear.

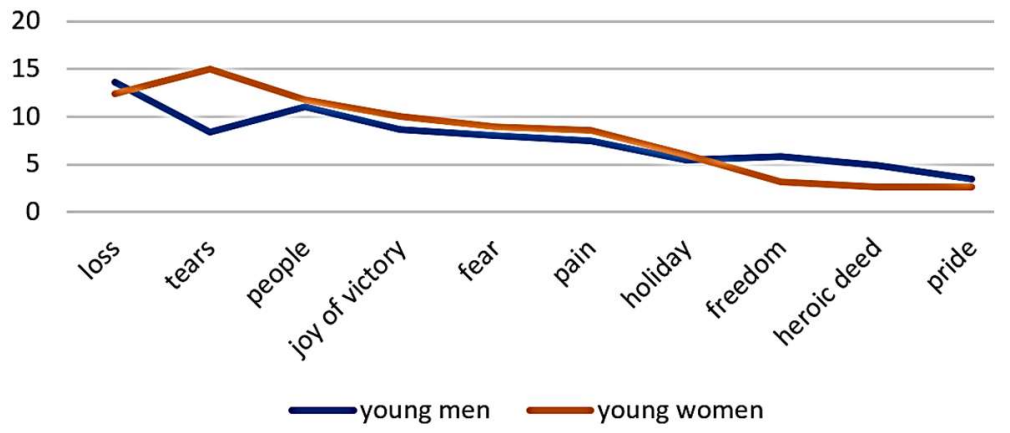

Fig. 1. Gender characteristics of the perception of war by university students.

At the same time, gender differences in these associations are also traced. Girls are more emotional in their perception of war. In the following table, a number of associations are grouped by topic (Table 2 ).

In the list of participants of the Second World War the historical memory of the war among the respondents, the people take priority place, followed by the veterans of the Second World War and relatives who lived during the war. Perhaps this indicates that student youth associate the victory in the Second World War with the efforts of the entire Soviet people. Historical figures of that time are practically not represented, Stalin is mentioned 7 times, Hitler - 4 times, M. Cantaria, G. Zhukov, U. Churchill. G. Truman - 1 time. The mention of Leningrad among the named associations, given the emotionally colored image of the war, most likely suggests that, according to the respondents, the inhabitants of the besieged city suffered more severe trials. The mention of Berlin is probably connected in student historical 
memory with the end of the Second World War. Military equipment is represented only by the BM-13 Katyusha field missile artillery system and the T-34 tank.

Table 2. Associations of students caused by the word «war».

\begin{tabular}{|c|c|c|}
\hline Associations & Number of respondents (out of 346) & $\%$ of respondents \\
\hline \multicolumn{3}{|c|}{ I. Geographical features } \\
\hline 1. Leningrad & 30 & 8.6 \\
\hline 2. Berlin & 24 & 6.9 \\
\hline 3. Stalingrad & 10 & 2.8 \\
\hline 4. & & \\
\hline 5. Moscow & 3 & 0.8 \\
\hline \multicolumn{3}{|c|}{ II. War veterans } \\
\hline 1. Veterans & 72 & 20.8 \\
\hline $\begin{array}{l}\text { 2. Grandmother, grandfather, } \\
\text { great-grandmother, great- } \\
\text { grandfather }\end{array}$ & 70 & 20.2 \\
\hline 3. Fascists & 32 & 9.2 \\
\hline 4. Soldiers & 26 & 7.5 \\
\hline 5. Nazis & 24 & 6.9 \\
\hline 6. I. Stalin & 7 & 2.0 \\
\hline 7. A. Hitler & 4 & 1.1 \\
\hline 8. M. Cantaria & 1 & 0.2 \\
\hline \multicolumn{3}{|c|}{ III. Military equipment } \\
\hline $\begin{array}{l}\text { 1. BM-13 Katyusha field } \\
\text { missile artillery system }\end{array}$ & 7 & 2.0 \\
\hline 2. T-34 tank & 4 & 1.1 \\
\hline
\end{tabular}

When answering the second question: «In your opinion, is it necessary to preserve the memory of the Great Patriotic War?» 99 percent of respondents said that it is necessary to preserve the memory of the Second World War. The answers to this question can be grouped as follows:

- You need to remember that this does not happen again - $44.7 \%$ of respondents;

- They answered «yes» without explanation - 13.2\%;

- It is necessary to preserve the memory of the Second World War, so that it would be possible to tell future generations about it $-11.5 \%$;

- You need to know not only the history of the Great Patriotic War, but also to study the history of your country, your people in general $-10.1 \%$;

- History repeats itself, without knowledge of the past it is impossible to understand the future $-4.6 \%$

- The memory of the war must be preserved in order to respect the past of their people, their ancestors, in gratitude $-4.3 \%$.

Generalized answers to the question: «How is it necessary to preserve the memory of the war?» can be formulated as follows:

- The state and society are conducting a sufficient number of events to maintain the memory of the war. It should be so! $-31.7 \%$;

- Memories are necessary, but it is necessary to avoid excessive spending on fireworks, parades, it is better to spend these funds on improving the quality of life of participants in the Second World War - 27.4\%;

- A lot of time has passed since the end of the war, many of the events held by the state are no longer relevant and do not carry anything except propaganda $-20.5 \%$;

- Most events take place in May. May 9 is not a holiday for me. This day should be a day of memory. We should not admire the deadly gun parade. One can include music in the city, military-historical films, ennobling burial places and monuments, helping veterans $-9.2 \%$. 
Answering question 4 of the questionnaire, and citing the most reliable sources, the overwhelming majority of respondents agree with the opinion that "the most reliable source about the war is the stories of relatives who went through this period". The category of reliable sources interviewed includes memories, photographs, autobiographies, letters from soldiers from the front, and oral stories. The following in terms of reliability are historical books, films, archival materials, art works museums, sites «Feat of the People», «Memorial».

Some of the respondents identified the media and Internet sources as unreliable.

A similar method of interviewing was used at the University of Arizona among students, which showed that the source of personal origin - family stories - is most trusted [17].

The influence of family history on the collective memory of students about the war is not always obvious. For several reasons, the memory of the war is not collected and preserved in all families, and a number of project participants claim that they began to be interested in the history of the family only as part of studying the history course at school and at the institute. Despite this, being a «reliable source», family history plays a significant role in the process of shaping the image of war among young people.

After conducting surveys and preliminary discussions, the next stage of work begins. Together with students, a further, individual for each, strategy is being developed to collect information about their relatives who lived during the war. Given the difficulties encountered by students in their first year of study, everyone who wishes to write their own history of the war is given recommendations on working with databases and writing scientific work. In the recommendations for working with databases, it is necessary to draw the attention of students to clarifying the following elements: dates, names of rivers, cities, military operations. Since the data in various sources may contradict each other, it is necessary to analyze the information found and verify it using geographical and historical Internet directories. In the recommendations for the design of scientific work, you should start with a plan, the title of the work and the structure of the presentation. Students pass these stages with the help and support of the teacher. The result of the work is the writing of stories about family history during the Second World War, the writing of scientific articles, some of which are published in the journal of KSUAE «Humanities in the $21^{\text {st }}$ century» [21]. This smart training technology has shown its effectiveness in the process of teaching history to students of a construction university and can be applicable in the study of any period of history by students of technical educational institutions.

\section{Discussions}

The aim of the article was an attempt to study several educational technologies, which we combined into the concept of «smart training». They affect the involvement of modern students in the process of studying historical science. Smart training includes a wide range of technologies that cannot be limited to online technologies only [11]. Training technology should include community-consolidating events. One of the important consolidating elements of modern Russian society is the memory of the events of the Great Patriotic War. Preservation of historical or collective memory is one of the ways of self-identification of a person, familiarization with the historical past of his country [2]. Moreover, collecting memories can attract students' interest in different periods of the country's history [22]. Therefore, it is very important to find out the attitude of students to these events in order to connect the student's daily personal experience with historical science through them. This approach has repeatedly become the subject of research by specialists in various fields of scientific knowledge [8]. Researchers focus not only on personally significant events for the student in the study of the subject, but in the interaction of the teacher, student and parents [14]. One of the important elements of the history teaching process of students of a technical university is personal interest in the process of cognition. In the formation of educational 
processes on the basis of historical memory, it is impossible to be limited only to archival, documentary and objective materials, but it is necessary to include both the impressions and experiences of the subject, the experience gained by him. Modern students are critical of the educational literature, trusting family stories and stories more [18]. Of great interest is the search for information about a loved one participating in the Great Patriotic War through electronic databases on the Internet. This in turn forms a research skill.

Researchers note the great importance of the survey and questionnaire among students as a method to determine the attitude of students to the historical past of the country. In this article, a survey showed that the patriotism of students and interest in history is primarily associated with traditional spiritual and moral family values. The sociocultural environment of the university and the personality of the professor, which contributes to the development of the ability to analyze and evaluate historical data, have a great influence on the perception of historical information [12]. Pedagogical technologies aimed at attracting students to collect materials on the history of their family contribute to the formation of a caring attitude to their country, its history and modernity. Purposeful educational and upbringing work, built taking into account social needs, makes it possible to adjust the value system and life plans of young people for their personal and social development [5]. The development of a student's personality is possible in the process of applying innovative educational technologies based on internally motivated activities [23]. The ability to work with the memories of participants in historical events forms a respectful attitude to the past of your country [20].

A survey of students showed that they are interested in preserving historical memory and studying history. It is important for the teacher to convey correctly information to the student, to interest him or her in the subject. Smart learning helps with that. Smart learning is a complex process that involves many elements. As a result, students form a skill of research, have personal interest, develop historical thinking, the ability to find information through Internet resources on their own, respect for the historical past of the country.

\section{References}

1. J. Dron. Smart learning environments, and not so smart learning environments: systems view. Smart Learn. Environ 5, 25 (2018). DOI: 10.1186/s40561-018-0075-9.

2. K. Gustafsson. Understanding the persistence of history-related issues in Sino-Japanese relations: from memory to forgetting. Int Polit International Politics (2020). ). DOI: 10.1057/s41311-020-00219-7.

3. A. Bermudez Haste, M. Carretero, S. Berger, M. Grever. The power of story: Historical narratives and the construction of civic identity, Palgrave handbook of research in historical culture and education, Palgrave Macmillan UK, London, England, 427-447 (2017). DOI: 10.1057 / 978-1-137-52908-4_23.

4. Yannis Hadzigeorgiou, Roland M. Schulz. Engaging Students in Science: The Potential Role of «Narrative Thinking» and «Romantic Understanding», Frontiers in Education, (2019). DOI: 10.3389/feduc.2019.00038.

5. O.G. Khripunova, A.A. Polyarush, E.V. Selivanova, E.V. Luneva. Undergraduate students' value orientations: Gender characteristics, Science for education today 5 (9), 24-35 (2019). DOI: 10.15293/2658-6762.1905.02.

6. K.J. Pugh, C.M. Bergstrom, B. Spencer. Profiles of transformative engagement: Identification, description, and relation to learning and instruction. Science Education 101, 369-398 (2017). DOI: 10.1002 / sce.21270.

7. D. Cunningham, L. Deborah. Understanding Pedagogical Reasoning in History Teaching through the Case of Cultivating Historical Empathy, Theory and Research in Social Education 35 (4), 592-630 (2007). DOI: 10.1080 / 00933104.2007 .10473352$. 
8. A. Kervinen, W. Roth, K. Juuti. The resurgence of everyday experiences in school science learning activities. Cult Stud of Sci Educ. (2020). DOI: 10.1007/s11422-019-09968-1.

9. Chen N. Kinshuk, I. Cheng. Evolution Is not enough: Revolutionizing Current Learning Environments to Smart Learning Environments, Int J. Artif. Intell. Educ. 26, 561-581 (2016). DOI: 10.1007/s40593-016-0108-x.

10. F.V. Nikolai, A.A. Mordvinov. "The Concept of «Courage» in Memories of Veterans of Local Wars: The Intersection of Oral History and Phenomenology of the Front-line Experience», Modern History of Russia 9 (2), 515-525 (2019). DOI: 10.21638/11701/spbu24.2019.213.

11. Z. Zhu, M. Yu, P. Riezebos. A research framework of smart education, Smart Learn. Environ 3, 4 (2016). DOI: 10.1186/s40561-016-0026-2.

12. B. Blevins, K. Magill, C. Salinas. Critical historical inquiry: The intersection of ideological clarity and pedagogical content knowledge, The Journal of Social Studies Research 44 (1), 35-50 (2020). DOI: 10.1016/j.jssr.2019.09.003.

13. B. Blevins, C. Salinas, T. Talbert. Critical historical thinking: Enacting the voice of the other in the social studies curriculum and classroom, Critical qualitative research in social education, Information Age Publishing, Charlotte, NC, 71-90 (2015). DOI: 10.13140/RG.2.1.3967.7285.

14. M.G. Nikitskaya, N.N. Tolstykh. Foreign studies of learning motivation: XXI century, Journal of Modern Foreign 7 (2), 100-113 (2018). DOI: 10.17759/jmfp. 2018070210.

15. Lévesque Stéphane, Nicholas Ng-A-Fook, Julie Corrigan. What Does the Eye See? Reading Online Primary Source Photographs in History, Contemporary Issues in Technology and Teacher Education 14 (2), (2014).

16. L.I. Rostovtseva, M.L. Gel'fond, E.Y. Miroshina. Patriotic education in experts and senior pupils' eyes. Sotsiologicheskie Issledovaniya 8, 75-83 (2019). DOI: 10.31857/S013216250006163-2.

17. Harris Lauren McArthur, Halvorsen Anne-Lise, Aponte-Martínez Gerardo J. "[My] family has gone through that»: How high school students determine the trustworthiness of historical documents, Journal of Social Studies Research 40 (2), 109-121 (2016). DOI: 10.1016/j.jssr.2015.06.007.

18. O.N. Cationov, A.O. Cationova, B.O. Mayer. Literary stories by military writers in the moral education of modern youth, Science for Education Today 1.9 (6), 107-120. DOI: 10.15293/2658-6762.1906.07.

19. I.A. Khaliy. Patriotism in the Russian: typology. Sociological Studies 2, 67-74 (2017).

20. S.A. Magaril. Meanings of Patriotism - Historical Transformation, Sociological Studies 1, 142-151 (2016).

21. M.S. Mikhailov, N.A. Mukhinova. «How do not I remember ...»: the history of the Great Patriotic War in the history of one family, Gumanitarnyye nauki v XXI veke 8, 47-52 (2017).

22. E.V. Bureeva. Student scientific project «Sovremennik» as a way to increase interest in studyinc history in modern youth, Baltic Humanitarian Journal 1 (34), 43-45 (2021). DOI: 10.26140/bgz3-2021-1001-0009.

23. Laila Yarullina, IOP Conf. Ser.: Mater.Sci.Eng. 890, 012171 (2020). DOI: $10.1088 / 1757-899 X / 890 / 1 / 012171$. 